O. ARKADIUSZ MIROSŁAW CZAJA OFM

Wydział Teologiczny Uniwersytetu Adama Mickiewicza w Poznaniu

\title{
ZNACZENIE MIŁOŚCI MAŁŻEŃSKIEJ W ASPEKCIE KANONICZNO-PASTORALNYM
}

Treść: Wstęp. - 1. Miłość a małżeństwo. - 2. Znaczenie miłości małżeńskiej. - 3. Miłość istotnym czynnikiem w przygotowaniu do małżeństwa. - 4. Miłość jako czynnik wpływający na świętość małżonków. - 5. Miłość małżeńska strażnikiem życia ludzkiego.

\section{Wstęp}

We współczesnych czasach dochodzi do wzrastającej liczby rozwodów cywilnych, dlatego należy podjąć starania mające na celu przypomnienie istoty i znaczenia małżeństwa, a co z tym szczególnie się łączy - znaczenia miłości małżonków, która ma swoje źródło w Bogu. Kościół katolicki od początku swojej posługi apostolskiej otacza małżeństwa i rodziny szczególną modlitwą, troską i błogosławieństwem. Istotnym czynnikiem, który ma wpływ na ich rozwój, jest miłość małżeńska. Ma ona zasadnicze znaczenie dla całej wspólnoty życia.

\section{Miłość a małżeństwo}

W małżeństwie uobecnia się miłość Chrystusa do Kościoła i jest to także wzór dla miłości małżeńskiej. Jezus włącza naturalną miłość mężczyzny i kobiety w swoją miłość do Kościoła. Małżeństwo jest wspólnotą życia oraz miłości, którą ustanowił Bóg, mającą charakter nieodwołalnej, osobistej zgody kobiety i mężczyzny: „Mężczyzna powiedział: «Ta dopiero jest kością z moich kości i ciałem z mego ciała! Ta będzie się zwała niewiastą, bo ta z mężczyzny została wzięta». Dlatego to mężczyzna opuszcza ojca swego i matkę swoją i łączy się 
ze swą żoną tak ściśle, że stają się jednym ciałem"'. Stanowi osobowy akt wzajemnego oddania się i przyjęcia. Jest świętym związkiem, a także dobrem całego społeczeństwa ${ }^{2}$. Zjednoczenie narzeczonych w małżeństwie wymaga pełnej wierności oraz wzajemnego oddania się małżonków.

W nauce Kościoła katolickiego od początku głosi się pogląd, że małżeńska, monogamiczna forma życia istnieje od zarania ludzkości. Bóg, pragnąc utrzymać rodzaj ludzki, przekazał człowiekowi $\mathrm{w}$ akcie stworzenia pragnienie do zakładania rodziny, które objawia się w naturalnej zdolności i skłonności mężczyzny oraz kobiety do posiadania potomstwa: „Stworzył więc Bóg człowieka na swój obraz, na obraz Boży go stworzył: stworzył mężczyznę i niewiastę. Po czym Bóg im błogosławił, mówiąc do nich: «Bądźcie płodni i rozmnażajcie się, abyście zaludnili ziemię i uczynili ją sobie poddaną"3.

Termin „małżeństwo” pochodzi z języka łacińskiego matrimonium. Składa się z dwóch wyrazów: mater, który tłumaczy się jako „matka” oraz munus oznaczającym „obowiązek”. Terminy te wskazują na szczególną rolę matki w rodzinie i w procesie wychowania dzieci. Jednakże nie umniejsza w niczym powinności ojca. Innym terminem na określenie małżeństwa, używanym w języku łacińskim, jest coniugium, który wywodzi się od wyrażenia commune iugum oznaczającego „wspólny ciężar i trud”. Wskazuje on na wspólne działanie żony i męża dla dobra założonej rodziny. Natomiast w przypadku polskiego określenia "małżeństwo”, domniemywa się, że pochodzi ono z połączenia dwóch wyrazów słowiańskich: „mał”, które oznacza „układ” oraz „żena” - co tłumaczy się jako „żona”, wskazując na uroczyste poślubienie kobiety przez mężczyznę $e^{4}$. Natomiast termin

\footnotetext{
${ }^{1} \mathrm{Rdz}$ 2, 23-24; por. 1, 27-28; W. Gór ALski, Małżeństwo kanoniczne, Warszawa 2011, s. 37.

${ }^{2} \mathrm{SC}, \mathrm{nr} 48$.

${ }^{3} \mathrm{Rdz}$ 1, 27-28; por. 2, 18; T. Pawluk, Prawo kanoniczne według Kodeksu Jana Pawła II. Prawo małżeńskie, T. 3, Olsztyn 1984, s. 21-22.

${ }^{4}$ Por. M. Al. Żurowski, Kanoniczne prawo małżeńskie Kościoła Katolickiego. Stan prawny po promulgowaniu Kodeksu Prawa Kanonicznego Kościoła Łacińskiego w 1983 r., Katowice 1987, s. 24; T. PAwluk, Prawo kanoniczne..., dz. cyt., s. 15.
} 
„małżeństwo”, jaki znajduje się w normach Kodeksu Prawa Kanonicznego, wskazuje na to, że jest wspólnotą całego życia mężczyzny i kobiety, powstałą w wyniku zawartego przymierza małżeńskiego, z natury zmierzającą do dobra małżonków oraz zrodzenia i wychowania dzieci. Chrystus podniósł rangę małżeństwa między ochrzczonymi do godności sakramentu ${ }^{5}$.

A zatem małżeństwo jest przymierzem, które tak, jak przymierze biblijne, oznacza umowę dwustronną. W Starym Testamencie wskazywało na relacje Boga do ludzi, a w Nowym Testamencie na miłość Chrystusa do Kościoła. Wspólnota życia, jako przymierze, wskazuje na to, że małżeństwo jest związkiem osobowym opartym na miłości i zaufaniu, jednocześnie dającym uprawnienia oraz rodzącym wzajemne zobowiązania względem siebie i całej rodziny ${ }^{6}$. To również trwały, wyłączny związek kobiety i mężczyzny, który jest następstwem zawartej prawnie umowy stanowiącej wspólnotę całego życia, w którym realizuje się cele, jakimi są: dobro małżonków, zrodzenie i wychowanie potomstwa ${ }^{7}$, a także dobro społeczne. Mąż i żona są wezwani do duchowego wzrostu, a w tym rozwoju winni sobie wzajemnie pomagać. Życie małżeńskie i rodzinne jest drogą do świętości, a zatem uczestnictwem w misji Kościoła katolickiego. Chrześcijańskie rozumienie małżeństwa w pełni uwzględnia wyjątkową naturę tej wspólnoty kobiety i mężczyzny. Małżeństwo to związek zawierany na całe ich życie i z tej racji pełni także określone zadania społeczne. Jedynie tak rozumianą wspólnotę mężczyzny i kobiety wolno nazywać małżeństwem. Przez sakrament małżeństwa miłość małżonków zostaje włączona w miłość Jezusa Chrystusa ${ }^{8}$. Tam, gdzie nie ma miłości małżeńskiej, tam małżonkowie są pozbawieni impulsów do

\footnotetext{
${ }^{5}$ CIC, can. 1055, § 1.

${ }^{6}$ Por. J. Laskowski, Małżeństwo chrześcijańskie w świetle kanonu 1055, Prawo Kanoniczne 34 (1991), nr 3-4, s. 139-40; W. Góralski, Małżeństwo kanoniczne..., dz. cyt., s. 27; M. Al. Żurowski, Kanoniczne prawo..., dz. cyt., s. 27-28.

${ }^{7}$ CIC, can. 1055, $\$ 1$.

${ }^{8}$ Por. J. Szy Ran, Sakrament małżeństwa buduje miłość małżeńska, życie rodzinne i społeczne (wspólnotowe), w: Sakramenty święte w życiu chrześcijańsko-franciszkańskim, praca zbiorowa, Warszawa 2006, s. 104.
} 
szczerego wypełnienia swoich zadań i obowiązków wynikających $\mathrm{z}$ małżeństwa i rodzicielstwa9.

O istotnej roli i zadaniach miłości małżeńskiej oraz rodzinnej mówił także Święty Jan Paweł II stwierdzając, że „Człowiek nie może żyć bez miłości. Człowiek pozostaje dla siebie istotą niezrozumiałą, jego życie jest pozbawione sensu, jeśli nie objawi mu się Miłość, jeśli nie spotka się z Miłością, jeśli jej nie dotknie i nie uczyni w jakiś sposób swoją, jeśli nie znajdzie w niej żywego uczestnictwa"10. Miłość jest umiejętnością wsłuchiwania się w potrzeby drugiego człowieka. Dzięki miłości człowiek posiada zdolność rozumienia problemów drugiej osoby. Miłość zmusza do patrzenia na człowieka jako całość, a nie tylko jako na sferę cielesną, intelektualną, czy duchową. Wszystkie działania niezgodne $\mathrm{z}$ naturą wyrządzają człowiekowi wielką szkodę ${ }^{11}$.

Życie małżeńskie i rodzinne w duchu chrześcijańskim domaga się dojrzałej miłości oraz dojrzałych relacji międzyosobowych ${ }^{12}$. Miłość, która wiąże kobietę i mężczyznę, ma swój początek w Bogu. Postawa życia dla drugiej osoby objawia się w obdarzaniu się wzajemnie miłością, a także przyczynia się do wszechstronnego rozwoju człowieka ${ }^{13}$. Ludzka miłość zostaje w sakramencie małżeństwa uświęcona przez miłość Bożą ${ }^{14}$. Prawdziwa miłość małżeńska domaga się całkowitego daru z siebie dla współmałżonka, bez jakichkolwiek ograniczeń ani warunków ${ }^{15}$. Człowiek stworzony przez Boga z miłości zostaje nią

\footnotetext{
${ }^{9}$ Por. U. Navarrete, Amor coniugalis et consensus matrimonialis, Periodica 67 (1976), s. 619-632.

${ }^{10} \mathrm{RH}, \mathrm{nr}$ 10; por. FC, nr 18; T. PAwluk, Prawo kanoniczne..., dz. cyt., s. 54.

${ }^{11}$ FC, nr 32; por. J. Szyran, Sakrament małżeństwa..., art. cyt., s. 105.

${ }^{12}$ Por. H. Stawniak, Udział małżonków w misji uświęcania przez prowadzenie życia matżeńskiego $w$ duchu chrześcijańskim, Studia Warmińskie XXXI (1994), s. 135.

${ }^{13}$ Por. J. Szyran, Sakrament małżeństwa..., art. cyt., s. 103-104.

${ }^{14}$ Por. Cz. Noworolnik, Miłość małżeńska - łaska sakramentu małżeństwa, Biblioteka Kaznodziejska 147 (2003), nr 5, s. 15-16.

${ }^{15}$ Por. H. Stawniak, Jedność i nierozerwalność małżeństwa, Prawo Kanoniczne 34 (1991), nr 1-2, s. 112.
} 
również obdarzony i jest zdolny kochać. Pragnienie miłowania i bycia miłowanym przez innych ludzi staje się przewodnim motywem działań osoby, zarówno w odniesieniu do Stwórcy, jak i do wszystkich ludzi ${ }^{16}$. Miłość z natury swojej jest twórcza, nie zamyka się w sobie i jest otwarta na dar życia. Przez małżonków najpełniej wyrażana jest stwórcza moc Boga, który powołuje do istnienia nowe życie ${ }^{17}$. Miłość małżeńska jest darem Boga, którą Stwórca obdarzył małżonków ${ }^{18}$.

Miłość mężczyzny i kobiety posiada charakter osobowy. Kobieta potrzebuje mężczyzny niejako dla uzupełnienia swojego bytu, tak samo jest w przypadku mężczyzny. Ta obiektywna potrzeba daje o sobie znać za pośrednictwem popędu seksualnego. Na podłożu tego popędu wyrasta między nimi miłość, która jest miłością pożądania. Wypływa ona z potrzeby i zmierza do dobra. Takim dobrem są wzajemnie dla siebie małżonkowie. Zachodzi jednak różnica miedzy miłością pożądania a samym pożądaniem. Miłość pożądania nie sprowadza się do samych pożądań, dlatego też miłość jest przeżywana jako pragnienie osoby, a nie jako samo pożądanie ${ }^{19}$.

W małżeństwie należy dbać o dobro drugiej strony, pomagać jej w doskonaleniu się i zbliżaniu do Boga. Miłość nie powinna zamykać i wyczerpywać się tylko w samej wspólnocie małżonków, lecz powinna zrealizować się w darze potomstwa. Miłość małżeńska i płodność stanowią podstawowe elementy odpowiedzialnego rodzicielstwa ${ }^{20}$, które polega na rozpoznaniu i podjęciu powołania

\footnotetext{
${ }^{16}$ Por. J. Szyran, Sakrament małżeństwa..., art. cyt., s. 103.

${ }^{17} \mathrm{KKK}, \mathrm{nr}$ 1604; por. W. GóRALSKI, Małżeństwo kanoniczne..., dz. cyt., s. 14; E. Sakowicz, Duchowość małżeńska, Homo Dei 71 (2001), nr 3, s. 61.

${ }^{18} \mathrm{~J}$ 4, 8; por. L. Pawlak, Duchowość małżeńska w świetle encykliki Humanae vitae, Studia nad Rodziną 6 (2002), nr 2, s. 112.

${ }^{19}$ Por. K. WojtyŁa, Miłość i odpowiedzialność. Studium etyczne, Londyn 1965, s. 57-64; G. ŁęCICKI, Małżeństwo i rodzina w nauczaniu oraz doświadczeniu Kościoła, Sandomierz 2011, s. 253.

${ }^{20}$ Konferencja Episkopatu Polski, Wskazania dla spowiedników w zakresie spowiedzi małżonków zalecone przez Episkopat Polski (26.01.1971), w: Dokumenty duszpastersko-liturgiczne Episkopatu Polski (1966-1998), Lublin 1999, cz. 1 (dalej: WSZSM), s. 83-98.
} 
małżeńskiego, polegającego na zrodzeniu oraz wychowaniu dzieci. Jeśli małżeństwo nie może zrodzić własnego potomstwa, zachęca się do adoptowania dzieci, które czekają na ich miłość. Odpowiedzialne rodzicielstwo wymaga, by małżonkowie zdawali sobie sprawę z tego, w jaki sposób powinni brać udział w realizacji Bożego planu stwórczego i zbawczego, w którym uczestniczą 21 . Święty Jan Paweł II odnosząc się do dramatu małżeństw, które nie mogą mieć dzieci z powodu niepłodności, wskazał im szczególną misję do spełnienia, podkreślając, że w takiej sytuacji życie małżeńskie nie traci z tego powodu swojej wartości. Wskazał, że niepłodność może dostarczyć małżonkom sposobności do innej ważnej służby na rzecz życia ludzkiego, jak na przykład adopcja, różne formy pracy wychowawczej, względem dzieci z ubogich rodzin lub też niesienie pomocy dzieciom upośledzonym ${ }^{22}$.

\section{Znaczenie miłości małżeńskiej}

Małżeństwo jest darem Bożym, w którym miłość stanowi ważny czynnik prowadzący małżonków wraz z rodziną do świętości. Miłość małżonków (amor coniugalis) jest bardzo ważnym czynnikiem, który wytwarza w nich wzajemne upodobanie oraz zbliża ich do siebie, powodując radość z wzajemnego ze sobą przebywania i otwiera na wzajemne potrzeby ${ }^{23}$. Należy przypomnieć słowa Świętego Pawła Apostoła o prawdziwej miłości, która powinna cechować małżonków: „Gdybym mówił językami ludzi i aniołów, a miłości bym nie miał, stałbym się jak miedź brzęcząca albo cymbał brzmiący. Gdybym też miał dar prorokowania i znał wszystkie tajemnice, i posiadał wszelką wiedzę, i wszelką [możliwą] wiarę, tak iżbym góry przenosił, a miłości bym nie miał, byłbym niczym. I gdybym rozdał na jałmużnę całą majętność moją, a ciało wystawił na spalenie, lecz

\footnotetext{
${ }^{21}$ Por. A. DzIĘGA, Prawny wymiar małżeńskiej wspólnoty osób, w: Kościelne Prawo Procesowe. Prawo Rodzinne. Materiały i Studia, red. tenże [i in.], T. 4, Lublin 2007, s. 19.

${ }^{22} \mathrm{FC}, \mathrm{nr}$ 14; por. G. ŁęCICKI, Małżeństwo i rodzina..., dz. cyt., s. 261-262.

${ }^{23}$ Por. W. Góralski, Małżeństwo kanoniczne..., dz. cyt., s. 51.
} 
miłości bym nie miał, nic bym nie zyskał. Miłość cierpliwa jest, łaskawa jest. Miłość nie zazdrości, nie szuka poklasku, nie unosi się pychą; nie dopuszcza się bezwstydu, nie szuka swego, nie unosi się gniewem, nie pamięta złego; nie cieszy się z niesprawiedliwości, lecz współweseli się z prawdą. Wszystko znosi, wszystkiemu wierzy, we wszystkim pokłada nadzieję, wszystko przetrzyma. Miłość nigdy nie ustaje, [nie jest] jak proroctwa, które się skończą, albo jak dar języków, który zniknie, lub jak wiedza, której zabraknie. Po części bowiem tylko poznajemy, po części prorokujemy. Gdy zaś przyjdzie to, co jest doskonałe, zniknie to, co jest tylko częściowe. Gdy byłem dzieckiem, mówiłem jak dziecko, czułem jak dziecko, myślałem jak dziecko. Kiedy zaś stałem się mężem, wyzbyłem się tego, co dziecięce. Teraz widzimy jakby w zwierciadle, niejasno; wtedy zaś [zobaczymy] twarzą w twarz. Teraz poznaję po części, wtedy zaś poznam tak, jak i zostałem poznany. Tak więc trwają wiara, nadzieja, miłość - te trzy: z nich zaś największa jest miłość"24.

Zdefiniowanie miłości jest trudne. Można spotkać się z różnymi jej interpretacjami. Jedni sprowadzają ją do afektywności, czyli do samych uczuć, inni do erotyki, czyli tylko do doznań seksualnych. Natomiast w aspekcie filozoficznym upatruje się związek miłości z dobrem, a w ujęciu teologicznym wskazuje się na odniesienie do Boga $^{25}$. Choć wiele jest interpretacji miłości, to wspólnym ich mianownikiem jest dążenie do zjednoczenia się dwojga ludzi dla dobra ich samych, a także dobra wspólnego ${ }^{26}$. Ponieważ miłość małżeńska powinna wyrażać się w trosce o dobro naturalne i nadprzyrodzone współmałżonka, dlatego każdy z małżonków ma obowiązek dostosowania się do potrzeb drugiej osoby.

Omawiając znaczenie miłości nie można zapominać o roli czynnika wolitywnego. Skutkuje on odpowiedzialnością za miłość między

\footnotetext{
${ }^{24} 1$ Kor $13,1-13$.

${ }^{25}$ Por. J. Laskowski, Wartość prawna miłości, Prawo Kanoniczne 33 (1990), nr 1-2, s. 134.

${ }^{26}$ Por. J. Szyran, Sakrament małżeństwa..., dz. cyt., s. 104; A. M. Czaja, Znaczenie i wartość prawna miłości małżeńskiej, Quaestiones Selectae XVIII (2011), nr 20, s. 10.
} 
małżonkami ${ }^{27}$. Wyróżnia się dwa rodzaje miłości: zmysłową - cielesną oraz duchową - objawiającą się pragnieniem i czynieniem dobra dla drugiej osoby. Życie małżeńskie łączy w sobie obydwa rodzaje miłości. Prawo kanoniczne zajmuje się zasadniczo miłością duchową, zależną w dużym stopniu od woli. Taka miłość jest darem z siebie i ukierunkowuje na drugą osobę ${ }^{28}$. Miłość wchodzi w zakres życia małżeńskiego, jednakże nie jest jej elementem bezwzględnym, lecz można śmiało stwierdzić, że stanowi czynnik integrujący. Nie ma ona wprost waloru prawnego, jednak spełnia bardzo ważną rolę w życiu małżeńskim, a tym samym w rodzinnym. Małżeństwo ważnie zawarte istnieje jako rzeczywistość prawna, choćby w życiu małżonków brakowało miłości ${ }^{29}$.

Prawdziwa miłość polega na skierowaniu woli ku osobie ukochanej, na szanowaniu jej dobra, na dawaniu i poświęcaniu siebie, a nie na egoizmie czy też na hedonizmie ${ }^{30}$. Wartość osoby jest zawsze wyższa aniżeli przeżywanych przyjemności ${ }^{31}$. Należy szukać dobra drugiej osoby oraz tego, co ją doskonali, a tym samym zbliża do Boga. Jednakże miłość małżeńska odłączona od Chrystusowego krzyża pozostaje jedynie na poziomie natury i nie ma w sobie mocy, aby wznieść się do życia nadprzyrodzonego. Miłość małżeńska powinna być także przyjaźnią kobiety i mężczyzny, a to wymaga równości i odpowiedzialnego udziału we wspólnie realizowanym powołaniu małżeńskim i rodzinnym. Powinna ona być wierna i wyłączna,

\footnotetext{
${ }^{27}$ Por. J. Laskowski, Wartość prawna..., art. cyt., s. 135-136.

${ }^{28}$ Por. R. Sztychmiler, Znaczenie prawne miłości małżeńskiej, Prawo Kanoniczne 38 (1995), nr 3-4, s. 87.

${ }^{29}$ Paulus VI, Allocutiones. Ad Praelatos Auditores, Advocatos et Officiales Tribunalis Sacrae Romanae Rotae, a Beatissimo Patre novo litibus iudicandis ineunte anno coram admissos, AAS 68 (1976), s. 206-207.

${ }^{30}$ Por. K. WoJTyŁA, Mężczyzną i niewiastą stworzył ich, Watykan 1986; J. ŻycińsKi, Osoba i miłość, Biblos 1993; J. Powell, Miłość bez warunków, Wrocław 1993.

${ }^{31}$ Por. K. WojtyŁa, Miłość i odpowiedzialność..., dz. cyt., s. 31; T. StyczeŃ, Problem człowieka problemem miłości, w: Człowiek w poszukiwaniu zaginionej tożsamości, Lublin 1987, s. 64-84; K. MAJDAŃsKI, Wspólnota życia i miłości, Warszawa 1983; W. SzEWCZy K, Miłość jako „zdecydowana wola wzajemnej promocji osób”, Tarnowskie Studia Teologiczne XIV (1995-1996), s. 94.
} 
jednakże nie może zamykać oraz wyczerpywać się tylko w swojej wspólnocie małżonków, lecz znaleźć możliwość wzajemnej realizacji $\mathrm{w}$ darze potomstwa.

Przed kanonistami stoi zadanie właściwego zdefiniowania znaczenia i roli miłości małżeńskiej. Pomocą w wypełnieniu tego zadania służy aktualna nauka Kościoła katolickiego dotycząca miłości małżeńskiej. Pierwszym dokumentem jest Konstytucja soborowa Gaudium et spes. Dokument ten nie ukazuje miłości małżeńskiej jako celu małżeństwa, lecz jako rzeczywistość, która jest skierowana ku dobru małżonków i dobru potomstwa jako celów małżeństwa ${ }^{32}$. Prawodawstwo kanoniczne rozumie miłość małżeńską nie w sensie erotycznym i psychologicznym, lecz jako dar $z$ siebie ${ }^{33}$. Istotne znaczenie w zrozumieniu waloru prawnego miłości małżeńskiej ma wyrok Trybunału Sygnatury Apostolskiej, który stwierdził, że jeśli miłość rozumie się jako akt woli (amor actus), poprzez który nupturienci przekazują się i przyjmują się wzajemnie, stając się małżeństwem, to miłość jest tym samym co zgoda małżeńska ${ }^{34}$. Znaczenie prawne miłości małżeńskiej można przyznać, jeśli rozumie się ją jako akt woli narzeczonych, przez który oni wzajemnie oddają i przyjmują w celu ustanowienia wspólnoty życia, a więc identycznie jak zgoda małżeńska ${ }^{35}$. Małżeństwo zawiera się poprzez wyrażenie całkowitej i dobrowolnej zgody ${ }^{36}$.

${ }^{32}$ GS, nr 49-50; por. W. Góralski, Małżeństwo kanoniczne..., dz. cyt., s. 51; A.M. Czaja, Podstawy kanonicznej wiedzy o małżeństwie i rodzinie. Pomoc duszpasterska dla młodzieży, narzeczonych i małżonków, Lublin 2011, s. 241.

${ }^{33}$ Por. W. Gór alski, Małżeństwo kanoniczne..., dz. cyt., s. 51-52.

${ }^{34}$ Dec. c. Staffa z 29.11.1975 r., Periodica 1977, nr 2, s. 315; por. W. GórAlski, Matżeństwo kanoniczne..., dz. cyt., s. 52.

${ }^{35}$ Por. A. Pastwa, Prawne znaczenie miłości małżeńskiej, Katowice 1999, s. 97-102; W. Góralski, Małżeństwo kanoniczne..., dz. cyt., s. 52-53.

${ }^{36}$ CIC, can. 1057, $\$ \$ 1-2$; por. W. Góralski, Tytuł VII. Małżeństwo, w: Komentarz do Kodeksu Prawa Kanonicznego z 1983 r. Księga III. Nauczycielskie zadanie Kościoła. Księga IV. Uświęcające zadanie Kościoła, red. P. Hemperek [i in.], T. 3, Lublin 1986, s. 253-254. 
Błogosławiony Paweł VI w przemówieniu do pracowników Trybunału Roty Rzymskiej stwierdził, że małżeństwo istnieje nawet, gdy miłość wygasa między małżonkami, a to z uwagi na to, że przyczyną sprawczą małżeństwa jest zgoda małżeńska. Przemówienie papieskie stwierdzało wyraźnie, że miłość nie ma wprost znaczenia prawnego w strukturze małżeństwa. Jednocześnie podkreśla, że powinna ona obejmować całego człowieka. Bez wzajemnej miłości małżonkowie są pozbawieni bodźców, które wpływają pozytywnie na wypełnianie celów małżeńskich ${ }^{37}$ oraz przymioty: jedność i nierozerwalność ${ }^{38}$ oraz sakramentalnośćc ${ }^{39}$, a zarazem budowanie trwałej wspólnoty rodzinnej. Miłość małżeńska jest gwarancją, że cele, jakie małżonkowie mają do spełnienia w swej wspólnocie, będą wykonane ${ }^{40}$. Cele małżeńskie nabierają szczególnej godności, jeśli przenika je wzajemna miłość małżeńska. Brak jej często wpływa na wzajemną awersję pomiędzy małżonkami, co przeważnie odciska się negatywnie na całej rodzinie.

Miłość małżeńska ma uzasadnienie biblijne i teologiczne. Można je również rozszerzyć o wymiar prawny, ponieważ jest ona ukierunkowania na dobro małżonków i prokreację oraz wychowanie dzieci4 ${ }^{41}$. Szczególną wartością cechuje się miłość, która przejawia się w formie cielesnej i duchowej, gdyż prowadzi do dobrowolnego oraz wzajemnego oddania się sobie. Sobór Watykański II podkreślił znaczenie w życiu małżeńskim miłości małżeńskiej, akcentując jednocześnie, że miłość prowadzi do zrodzenia i wychowania potomstwa oraz do głębokiej wspólnoty życia. Taka miłość nadaje szczególną wartość małżonkom, prowadząc ich do dobrowolnego i wzajemnego oddania się sobie oraz przenika ich życie ${ }^{42}$. Natomiast papież Pius XI stwierdził, że miłość małżeńska przenika wszystkie obowiązki

${ }^{37}$ CIC, can. 1055, \$1; por. Z. Grocholewski, Sakrament małzeństwa: fundament teologiczny prawodawstwa kościelnego, Prawo Kanoniczne 40 (1997), nr 1-2, s. 180; P.M. Gajda, Prawo małżeńskie Kościoła katolickiego, Tarnów 2002, s. 50.

${ }^{38}$ CIC, can. 1056; por. W. Góralski, Tytuł VII. Małżeństwo, art. cyt., s. 252-253.

${ }^{39}$ CIC, can. 1055, § 1; por. W. GóRALsKi, Tytuł VII. Małżeństwo, art. cyt., s. 252.

${ }^{40}$ Por. T. Pawluk, Prawo kanoniczne..., dz. cyt., s. 53.

${ }^{41}$ GS, nr 49-50; por. R. SzTychmiler, Znaczenie prawne..., art. cyt., s. 90-91.

${ }^{42}$ GS, nr 49; por. T. Pawluk, Prawo kanoniczne..., dz. cyt., s. 53. 
życia małżeńskiego ${ }^{43}$. Podkreślić należy także wartość osobowej unii małżeńskiej i rolę miłości małżeńskiej ${ }^{44}$. Małżonkowie muszą być świadomi, że życie płciowe jest usankcjonowane przez Boga wówczas, gdy całkowicie ofiarują siebie wzajemnie, a kochać drugiego człowieka w małżeństwie oznacza kochać go w Bogu ${ }^{45}$. Małżeństwo oparte jest na miłości, która jest bezinteresownym darem $\mathrm{z}$ siebie $^{46}$.

\section{Miłość istotnym czynnikiem w przygotowaniu do małżeństwa}

Odpowiedzialne zawieranie małżeństwa uwzględnia wartość miłości, która powinna znajdować się u podłoża wspólnego życia ${ }^{47}$. Dlatego bardzo ważne dla formacji dzieci, młodzieży, a następnie dla narzeczonych jest okres przygotowania do małżeństwa i życia rodzinnego, które rzutuje na całe ich przyszłe życie. Nie wystarczy urodzić dzieci, ale także należy je solidnie wychować i zapewnić im warunki do właściwego rozwoju. Najłatwiej to zadanie wypełnia się przez wspólnotę rodzinną opartą na trwałym, wiernym związku małżeńskim oraz na wzajemnej miłości rodziców. Rodzice mają być nie tylko celem chrześcijańskiego wychowania rodzicielskiego, ale i sami powinni aktywnie włączyć się w apostolstwo. Duszpasterz powinien mieć w rodzicach przedłużenie własnego oddziaływania w głoszeniu Ewangelii. W tym posłannictwie wychowawczym wzorem jest Jezus Chrystus.

\footnotetext{
${ }^{43}$ Pius IX, Enc. Castr connubii, 31.12.1930, w: AAS 22 (1930), s. 547-548.

${ }^{44}$ Por. K. HoŁdA, Przymierze małżeńskie w świetle nauki Pisma św. i Tradycji, Ruch Biblijny i Liturgiczny nr 6 (1987), s. 488-496; W. Góralski, Matżeństwo kanoniczne..., dz. cyt., s. 28.

${ }^{45}$ Por. A. Sobczak, Miłość małżeńska i cele małżeństwa według Dietricka von Hildebranda, Studia Gnesnensia XV (2001), s. 196.

${ }^{46}$ Por. GE, nr 3; AA, nr 30; Konferencja Episkopatu Polski, Instrukcja Episkopatu Polski dla duchowieństwa o przygotowaniu wiernych do sakramentu małżéstwa i o duszpasterstwie rodzin (12 II 1969), w: Dokumenty duszpastersko-liturgiczne Episkopatu Polski (1966-1998), Lublin 1999, cz. IV, nr 2 (dalej: IEP1).

${ }^{47}$ Por. J. Laskowski, Wartość prawna..., art. cyt., s. 139; J. Baniak, Dialog w matżeństwie i rodzinie jako czynnik więzi i trwałości wspólnotowej, Poznańskie Studia Teologiczne 14 (2003), s. 175-212.
} 
Przygotowanie do życia małżeńskiego, a tym samym do rodzinnego, jest zadaniem całego Kościoła katolickiego. Rozpoczyna się od najmłodszych lat i trwa do momentu zawarcia małżeństwa, a następnie przechodzi w etap formacji rodzinnej. Całą formację małżeńsko-rodzinną można podzielić na cztery etapy. Trzy z nich - dalszy, bliższy i bezpośredni - są realizowane przed zawarciem małżeństwa. Natomiast czwarty obejmuje pomoc duszpasterską małżonkom i rodzinie, którą założyli. Prawodawca kościelny zobowiązuje duszpasterzy do otoczenia szczególną troską rodzin, wskazując na konkretne formy tej pomocy. Sposób oraz formy przeprowadzenia przygotowania należy dostosować do przepisów prawa kanonicznego.

Pierwszym etapem formacji do życia w małżeństwie jest przygotowanie dalsze. Okres ten rozpoczyna się już w dzieciństwie poprzez wychowanie w rodzinie. Celem przygotowania dalszego jest stworzenie wspólnoty rodzinnej, która zostanie oparta na: miłości, religijności, zgodzie, wierności, wzajemnej życzliwości, zrozumieniu, szacunku dla całej rodziny i innych ludzi ${ }^{48}$. Etap ten jest wstępnym okresem kształtowania w młodym człowieku poczucia odpowiedzialności, które ma swój początek w wychowaniu rodzinnym oraz katechezie szkolnej ${ }^{49}$. Nie można zapominać, że to rodzina jest podstawowym miejscem wychowania, jak i katechizowania, wyprzedza więc każdą inną formę nauczania przeprowadzaną przez innych. Jest najlepszym środowiskiem do przygotowania do życia małżeńskiego i rodzinnego, poprzez przykład miłości rodziców, która powinna ogarnąć wszystkich członków rodziny. Rodzice mają pierwszeństwo

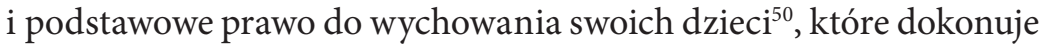
się poprzez ukazanie odpowiednich wzorców oraz nauczanie umie-

\footnotetext{
${ }^{48} \mathrm{KKK}, \mathrm{nr}$ 1631; por. K. Dullak, Przygotowanie do sakramentu małżeństwa w ujęciu pokodeksowego ustawodawstwa synodalnego w Polsce do 2001 roku, Prawo Kanoniczne 47 (2004), nr 1-2, s. 61-76.

49 Papieska Rada ds. Rodziny, Przygotowanie do sakramentu małżéstwa, 13.05.1996, Wrocław 2000, nr 22 (dalej: PdSM); por. M. FĄKA, Małżeńskie prawo kościelne, w: Katolicyzm A-Z, red. Z. Pawlak, Łódź 1989, s. 236.

${ }^{50} \mathrm{KKK}, \mathrm{nr}$ 1657; por. FC, nr 36-37; J. Skreczko, Wychowanie. Prawo rodziców, w: Słownik małżeństwa i rodziny, red. E. Ozorowski, Warszawa - Łomianki 1999, s.
} 
jętności dojrzałego patrzenia na małżeństwo i rodzinę. Prawidłowe wychowanie w rodzinie jest podstawą dojrzałej osobowości młodego pokolenia, co nie jest możliwe bez przykładu wzajemnej miłości rodziców. Miłość ta ma ogromne znaczenie dla rozwoju i formacji dzieci ${ }^{51}$. Święty Jan Paweł II nauczał, że przygotowanie dalsze rozpoczyna się w dzieciństwie, w którym to okresie powinno się uczyć młode pokolenie szacunku dla wartości ludzkich w stosunkach międzyosobowych i społecznych. Idąc za wskazaniami Papieża, zadaniem rodziny jest przekazywanie wartości, które budują wspólnotę rodzinną.

Poprzez formację powinno się ukazać małżeństwo jako powołanie $^{52}$. A zatem zadaniem rodziców jest przygotowanie dzieci, by osiągnęły dojrzałość i mogły odpowiedzialnie odczytać swoje powołanie. Rodzice powinni być przewodnikami, wzorami miłości małżeńskiej i rodzinnej, wspierającymi swoje dzieci przez udzielanie mądrych i roztropnych pouczeń oraz przykładów ${ }^{53}$. Na kształtowanie młodego pokolenia ma duży wpływ cała rodzina. W obecnych czasach tak łatwo zapomina się, że istotny wpływ na formację dzieci ma obecność rodziców, wzajemna współpraca ojca i matki w kształtowaniu swojego potomstwa. Osoby pochodzące z rodzin pełnych tworzą w przyszłości małżeństwo trwałe, znacznie częściej niż osoby, które wychowały się $\mathrm{w}$ rodzinach rozwiedzionych ${ }^{54}$.

Drugim etapem formacji do zawarcia małżeństwa jest przygotowanie bliższe, które jest kontynuacją i pogłębieniem przygotowania dalszego. Obejmuje ono młodzież ponadgimnazjalną w ramach katechezy przedmałżeńskiej. Przygotowanie bliższe ma na celu pogłębienie

476; J. Stala, Katecheza rodzinna. Próba teologicznego zarysu zagadnienia, w: Rodzina bezcenny dar i zadanie, red. tenże [i in.], Radom 2006, s. 197.

${ }^{51}$ Por. CT, nr 68, S. AdAмсzyк, Przygotowanie do małżeństwa w warunkach Kościoła w Polsce, Sandomierz 2002, s. 109-110.

${ }^{52} \mathrm{FC}, \mathrm{nr} 66$.

${ }^{53}$ Konferencja Episkopatu Polski, List Rady ds. Rodziny - „in vitro”, 08.12.2007, w: www.episkopat.pl, nr 16; por. G. PyźLAK, Recepcja przygotowania do małżeństwa w świetle badań narzeczonych, Lublin 2007, s. 19.

${ }^{54}$ Por. J. Laskowski, Trwałość wspólnoty małżeńskiej, Warszawa 1987, s. 162; S. Adamczy к, Przygotowanie do małżeństwa..., dz. cyt., s. 109. 
chrześcijańskiej wiedzy o małżeństwie i rodzinie, jak i wprowadzenie w aktywne uczestnictwo w życie Kościoła katolickiego ${ }^{55}$. Okres ten powinien obejmować również zagadnienia związane ze znaczeniem miłości małżeńskiej i rodzinnej. Troska o młodzież jest również wyrazem miłości rodziców, dlatego należy młode pokolenie przestrzec przed współczesnymi ideologiami niezgodnymi z nauką Kościoła, które uderzają w godność i trwałość małżeństwa oraz rodziny. Katecheza przedmałżeńska ma przede wszystkim formować, jednakże ze względu na szeroki zakres materiału w tej kwestii i na różny poziom świadomości religijnej młodego pokolenia oraz różny stopień jej zaangażowania się w życie Kościoła, konieczne jest dostosowanie odpowiednich form przygotowania do małżeństwa, uwzględniające stopień rozwoju i wiedzę konkretnej osoby.

Istotnym elementem $\mathrm{w}$ przygotowywaniu młodych ludzi jest uświadomienie im, że czystość przedmałżeńska jest bardzo ważnym czynnikiem, który wpływa nie tylko na ich przyszłe małżeństwo, ale także na rodzinę, którą mają zamiar założyćc ${ }^{56}$. Jeżeli osoby pragnące zawrzeć małżeństwo nie przestrzegają czystości, jednocześnie wiedząc, że jej zachowanie jest obowiązkiem i świadomie oraz dobrowolnie go łamią, to w przeważającej liczbie przypadków nie będą przestrzegać również wierności małżeńskiej. A zatem źródło problemów małżeńskich oraz przyczyn rozejścia się małżonków można zaobserwować już w okresie przedmałżeńskim. Osoby niewychowane w szacunku dla zasad przedmałżeńskich są bardziej narażone na wzajemne zdrady, które doprowadzają do rozpadu życia małżeńskiego, a tym samym rodzinnego. Dlatego w trakcie kształcenia młodego

\footnotetext{
${ }^{55}$ Konferencja Episkopatu Polski, Powołanie do życia $w$ małżeństwie i rodzinie, w: II Polski Synod Plenarny (1991-1999), Pallottinum 2001, nr 42 (dalej: PSPP); por. J. KŁęCzeк, W. Szewczy , Wspierać „Kościół domowy”. Powołanie do życia w małżeństwie i rodzinie, w: W trzecie tysiąclecie. Komentarz pastoralny do dokumentów II Polskiego Synody Plenarnego, red. W. Lechowicz, Tarnów 2002, s. 28-29; S. AdAmczy K, Przygotowanie do małżństwa..., dz. cyt., s. 124.

${ }^{56}$ Por. G. Łęcicki, Małżeństwo i rodzina..., dz. cyt., s. 264; H. Schneider, Prawdziwa miłość czeka. Szóste Przykazanie ze szczególnym uwzględnieniem wstrzemięźliwości aż do czasu matżeństwa, Sprawy nad Rodziną (2006), nr 65, s. 89-105.
} 
człowieka należy uświadomić go, że miłość małżeńska to nie tylko współżycie cielesne, lecz szczególne wymaganie od siebie, a także od drugiej osoby oraz poszanowanie wartości chrześcijańskich. Osoby, które nie szanują zasad przedmałżeńskich i małżeńskich, lekceważą naukę Jezusa Chrystusa.

Trzecim etapem jest przygotowanie bezpośrednie do zawarcia małżeństwa, a tym samym do założenia nowej rodziny. Formacja ta powinna się rozpocząć kilka miesięcy przed ustaloną datą ślubu. Zakres przygotowania bezpośredniego powinien cały czas pogłębiać w narzeczonych wiarę oraz świadomość znaczenia łaski Bożej oraz odpowiedzialności chrześcijańskiej, jak również przygotować ich do podjęcia czynnego oraz świadomego udziału w liturgicznym obrzędzie małżeństwa ${ }^{57}$. W duszpasterstwie spotyka się sytuacje, że brak wcześniejszego przygotowania ujawnia się dopiero przy zgłoszeniu się narzeczonych w kancelarii parafialnej w celu zawarcia małżeństwa. W takich sytuacjach należy podjąć się ich edukacji religijnej, a także położyć duży nacisk na formowanie w nich życia religijnego oraz na przekazanie zasad wiary, moralności i miłości chrześcijańskiej ${ }^{58}$. Prawodawca kościelny wymaga od narzeczonych do zawarcia ślubu jasno określonego przygotowania i posiadania odpowiedniej dyspozycji. W instytucji małżeństwa i rodziny zakłada się w swej istocie pewien konieczny stopień dojrzałości chrześcijańskiej. Dlatego jednym z wymogów przed przystąpieniem do sakramentu małżeństwa jest przyjęcie sakramentu bierzmowania ${ }^{59}$. Katolicy są zobowiązani do przyjęcia tego sakramentu, gdyż Dar Ducha Świętego ma w nich uformować dojrzałą i głęboką wiarę w Boga ${ }^{60}$.

\footnotetext{
${ }^{57}$ FC, nr 66; por. PdSM, nr 52; J. KŁęCZek, W. SzEWCZyк, Wspierać Kościół..., art. cyt., s. 30-32.

${ }^{58}$ Por. Konferencja Episkopatu Polski, Instrukcja Episkopatu Polski o przygotowaniu do zawarcia małżeństwa w Kościele katolickim, 05.09.1986, w: Dokumenty duszpastersko-liturgiczne Episkopatu Polski (1966-1998), Lublin 1999, nr 10-14 (dalej: IEP3).

${ }^{59}$ CIC, can. 1065, § 1; por. W. GóRALSKI, Tytuł VII. Małżeństwo, art. cyt., s. 226.

${ }^{60} \mathrm{KKK}, \mathrm{nr} 1309$.
} 
Katecheza przedślubna powinna obejmować zagadnienia $\mathrm{z}$ teologii małżeństwa, etyki życia małżeńskiego i liturgii sakramentu małżeństwa, a poza tym należy również poruszyć temat, czym jest miłość małżeńska i rodzicielska ${ }^{61}$. Konieczność przygotowania bezpośredniego istnieje zawsze, ale szczególnie wtedy, gdy narzeczeni mają braki w wiedzy o życiu małżeńskim i rodzinnym, a także nie praktykują życia chrześcijańskiego. Jedną z form w ramach przygotowania bezpośredniego są badania przedślubne. Mają one na celu rozeznanie sytuacji narzeczonych, przede wszystkim odnośnie ich stanu wolnego oraz stwierdzenia pełnej swobody i dobrowolności w podejmowaniu decyzji o małżeństwie. Badania dotyczą przeszkód małżeńskich, wymogów stawianych w kwestii zgody małżeńskiej, formy zawierania małżeństwa oraz wszystkiego tego, co wiąże się z jego ważnością i godziwością ${ }^{62}$.

Jezus Chrystus uczynił małżeńst wo między ochrzczonymi sakramentem. Dlatego narzeczonych przygotowujących się do małżeństwa zachęca się, by uczestniczyli w rekolekcjach bądź dniach skupienia organizowanych w parafiach. Pozwalają one na dobre przysposobienie się do wielkiego powołania, jakim jest zawarcie małżeństwa i założenie nowej rodziny ${ }^{63}$. Sakrament małżeństwa jest uczestnictwem w darze miłości Chrystusa ${ }^{64}$, dlatego narzeczeni powinni wcześniej przystąpić do sakramentu pokuty, by w czasie liturgii sakramentu małżeństwa przyjąć Komunię Świętą i w ten sposób rozpocząć nowy etap swojego życia w łasce Bożej godziwie ślubując ${ }^{65}$. Szafarzami tego sakramentu są sami małżonkowie.

Narzeczeństwo to kolejna forma przygotowania bezpośredniego, by przekonać się, czy łączy ich prawdziwa miłość, czy też jest to

${ }^{61}$ Por. Konferencja Episkopatu Polski, Dyrektorium duszpasterstwa rodzin. Dokument został przyjęty podczas 322 Zebrania Plenarnego Konferencji Episkopatu Polski w Warszawie, 01.05.2003, Warszawa 2003, nr 30 (dalej: Ddr).

${ }^{62}$ CIC, can. 1066-1067; por. W. Gór ALski, Tytuł VII. Małżeństwo, art. cyt., s. 227.

${ }^{63}$ PSPP, nr 41; por. IEP3, nr 20; Ddr, nr 30.

${ }^{64}$ Por. J. Buxakowski, Dary Sakramentu Małżeństwa, Sprawy Rodziny (1999), nr 1 (48), s. 41.

${ }^{65}$ CIC, can. 1065, § 2; por. W. Góralski, Tytuł VII. Małżeństwo, art. cyt., s. 226-227. 
chwilowe wzajemne zauroczenie. Jest to szczególny okres w przygotowaniu do małżeństwa, który ma na celu wzajemne poznanie się kobiety i mężczyzny. Zazwyczaj rozpoczyna się zaręczynami ${ }^{66}$. Instytucja zaręczyn sięga czasów starożytnych. Przewidywało je prawo babilońskie, żydowskie i rzymskie, a także było praktykowane w pierwszych gminach chrześcijańskich ${ }^{67}$. Zwyczaj ten ma formę spotkania się rodzin narzeczonych pragnących zawrzeć $\mathrm{w}$ najbliższym czasie małżeństwo oraz oświadczenia mężczyzny o pragnieniu poślubienia wybranej kobiety ${ }^{68}$. Obecne prawodawstwo kanoniczne uznało, że jest wskazane nawiązać do tego wielowiekowego zwyczaju oraz ożywić tę formę przygotowania do małżeństwa ${ }^{69}$. Zaleca, aby uroczystość zaręczyn odbyła się przynajmniej na sześć miesięcy przed planowanym zawarciem małżeństwa.

Na obrzęd zaręczyn składa się oznajmienie mężczyzny, że pragnie poślubić wybrankę oraz przyjęcie jego oświadczyn przez nią samą. Cała uroczystość zaręczyn ma charakter święta rodzinnego ${ }^{70}$. Przyrzeczenie powinno mobilizować narzeczonych do odnoszenia się do siebie z szacunkiem, podyktowanym dobrem planowanego w przyszłości małżeństwa. Jednakże nie mogą oni korzystać z uprawnień, które z prawa Bożego przysługują wyłącznie małżonkom. Mają obowiązek zachowania czystości przedmałżeńskiej. Zaręczyny nie pociągają za sobą skutków prawnych w Kościele katolickim, wiążą jedynie narzeczonych w sumieniu. Są oni moralnie zobowiązani do wzajemnej lojalności i szacunku. Umowa zaręczynowa nie obliguje bezwzględnie do zawarcia małżeństwa. Możliwe natomiast jest dochodzenie wynagrodzenia za ewentualne szkody lub poniesienie

\footnotetext{
${ }^{66}$ Por. CIC, can. 1062, \$1; por. J. GlaPIAK, Praktyczny przewodnik po przepisach prawa kościelnego, Poznań 2012, s. 89.

${ }^{67}$ Por. A. B£awat, Zaręczyny, w: Słownik małżeństwa i rodziny, red. E. Ozorowski, Warszawa - Łomianki 1999, s. 497.

${ }^{68}$ Por. Tamże, s. 496.

${ }^{69}$ Por. CIC, can. 1062, \$ 1; por. Ddr, nr 28; M. SitARz, Zaręczyny, w: Słownik prawa kanonicznego, red. tenże, Warszawa 2004, kol. 201; M. FĄKA, Małżeńskie prawo kościelne, w: Katolicyzm A-Z, red. Z. Pawlak, Łódź 1989, s. 237.

${ }^{70}$ Por. J. Wysocki, Rytuał rodzinny, Włocławek 2003, s. 531-532.
} 
wydatków materialnych, powstałych z racji małżeństwa zamierzonego, ale niedoszłego do skutku ${ }^{71}$.

Okres narzeczeństwa, połączony z poważnym i odpowiedzialnym przygotowaniem do małżeństwa, może przyczynić się do podjęcia dojrzałej i odpowiedzialnej decyzji. Przyczyną problemów w małżeństwie jest lekkomyślność i pośpiech w jego zawieraniu, brak odpowiedniego i wystarczającego wzajemnego poznania się narzeczonych. Dlatego w okresie narzeczeństwa młodzi powinni nie tylko poznać wzajemnie swoje charaktery, zalety, umiejętności oraz ewentualnie wady bądź nałogi i obciążenia dziedziczne, ale także środowiska, z których się wywodzą ${ }^{72}$. Narzeczeni zobowiązani są do lojalności względem siebie ${ }^{73}$.

Zawarcie małżeństwa nie kończy formacji duszpasterskiej względem nowożeńców, lecz rozpoczyna czwarty etap, jakim jest życie rodzinne. Wprowadza on ich w pełną możliwości współpracę z Chrystusem i Kościołem poprzez korzystanie z sakramentów świętych, szczególnie z sakramentu pokuty, uczestnictwa w Eucharystii, katechezie oraz przez troskę o wychowanie dzieci. Błogosławiony Paweł VI zachęcał, aby małżonków przygotować należycie do tego, by jak najczęściej, z głęboką wiarą przystępowali do sakramentu pokuty i Komunii Świętej oraz by nigdy nie upadali na duchu z powodu własnej słabości i przeżywanych trudności ${ }^{74}$.

Życie rodzinne charakteryzuje się istnieniem wspólnotowym, którego celem jest pełny rozwój człowieka i utrwalenie wzajemnych relacji rodzinnych ${ }^{75}$. Wspólnota kościelna jest zobowiązana do pomocy, aby małżonkowie szli drogą właściwą ich stanowi i zachowali ducha chrześcijańskiego. W tym celu pomocna jest katecheza

${ }^{71}$ CIC, can. 1062, \$2; por. M. SitARZ, Zaręczyny, art. cyt., kol. 201; W. GóRALSKI, Tytuł VII. Małżeństwo, art. cyt., s. 228; M. FĄKA, Małżeńskie prawo..., dz. cyt., s. $236-237$.

${ }^{72}$ Por. IEP3, nr 30-34.

${ }^{73}$ Por. J. Glapiak, Praktyczny przewodnik..., dz. cyt., s. 90.

${ }^{74} \mathrm{HV}, \mathrm{nr}$ 29; por. IEP1, cz. III, nr $1 \mathrm{~b}$.

${ }^{75}$ Por. J.R. Ruszczyński, Sens życia rodzinnego, w: Słownik małżéstwa rodziny, red. E. Ozorowski, Warszawa - Łomianki 1999, s. 420. 
małżeńska, która powinna obejmować: konferencje formacyjne dla młodych małżeństw, łączone zawsze ze wspólnymi modlitwami przy czynnym współudziale wiernych świeckich; przeprowadzanie nauk stanowych, nawiązujących do problematyki współczesnych zainteresowań i konkretnych sytuacji w małżeństwie oraz udostępnianie przez duszpasterza odpowiednich materiałów z literatury naukowej, które umożliwią indywidualne studium i pogłębienie problematyki życia w małżeństwie i rodzinie. Treścią katechizacji powinny być różnorodne problemy, jakie mogą pojawić się w życiu oraz rozwiązywanie ich w świetle nauki ewangelicznej ${ }^{76}$.

Rodzina jest pierwszym i podstawowym miejscem formacji ludzkiej i katechizowania dzieci. Rodzice mają prawo pierwszeństwa wychowania swoich dzieci ${ }^{77}$. Wyprzedza ono każdą inną formę nauczania, jest więc najlepszym środowiskiem do przygotowania do życia małżeńskiego i rodzinnego. Dokonuje się to poprzez ukazywanie przez rodziców odpowiednich wzorców oraz uczenie umiejętności dojrzałego patrzenia na małżeństwo i rodzinę, co ma zaowocować w przyszłości, w ich dorosłym życiu. Święty Jan Paweł II podkreślał, że rodzina mająca początek w miłości Boga stanowi pierwszą, najważniejszą i powszechną drogę Kościoła, a zarazem centrum oraz serce cywilizacji miłości, w przypomnieniu istoty miłości, wizji człowieka jako daru $z$ siebie, zasad odpowiedzialnego rodzicielstwa. Papież nauczał o obowiązku dawania świadectwa świętości życia małżeńskiego i rodzinnego na wzór Świętej Rodziny ${ }^{78}$. Prawidłowe wychowanie w rodzinie jest podstawą dojrzałej osobowości młodego pokolenia, a także w przyszłości kolejnych pokoleń, jednakże bez czynnika, jakim jest miłość małżeńska i rodzicielska, nie jest to możliwe.

\footnotetext{
${ }^{76}$ Por. IEP1, cz. III, nr la.

${ }^{77}$ KKK, nr 1657; por. FC, nr 36-37; A. Skreczko, Wychowanie. Prawo rodziców, w: Słownik małżństwa i rodziny, red. E. Ozorowski, Warszawa - Łomianki 1999, s. 476; J. Stala, Katecheza rodzinna. Próba teologicznego zarysu zagadnienia, w: Rodzina bezcenny dar i zadanie, red. tenże [i in.], Radom 2006, s. 197.

${ }^{78}$ Jan PaWeŁ II, List do Rodzin Gratissimam sane, 02.02.1994, Rzym 1994, nr 20-23; nr 82-99; por. G. ŁĘCICKI, Małżeństwo i rodzina..., dz. cyt., s. 271-272.
} 


\section{Miłość jako czynnik wpływający na świętość małżonków}

Wielką rolę w przezwyciężaniu grzechu i umacnianiu się w miłości ma Sakrament Najświętszej Eucharystii, który jest źródłem życia i siłą dla wszystkich ludzi. Udział w życiu sakramentalnym, szczególnie poprzez częste korzystanie z sakramentu pokuty i Eucharystii, połączone z codzienną modlitwą, kształtuje chrześcijańską postawę małżonków ${ }^{79}$. Małżeństwo przynależy do porządku naturalnego i nadprzyrodzonego, który prowadzi chrześcijan do świętości. Chrześcijanie poprzez sakrament małżeństwa są powołani do miłości i szczęścia doczesnego oraz wiecznego. Istota duchowości małżeńskiej wyraża się w ich uczestnictwie w miłości Boga.

Wzorem w życiu małżeńskim i rodzinnym jest Święta Rodzina, gdzie przykładem dla każdej matki jest Najświętsza Maryja Panna, a dla ojca - Święty Józef Opiekun. Małżeństwo jest obrazem Mistycznego Ciała Chrystusa oraz cząstką Ludu Bożego. Małżeństwo jest dziełem Boga: „Stworzył więc Bóg człowieka na swój obraz, na obraz Boży go stworzył: stworzył mężczyznę i niewiastę. Po czym Bóg im błogosławił, mówiąc do nich: «Bądźcie płodni i rozmnażajcie się, abyście zaludnili ziemię i uczynili ją sobie poddaną (...)»"80.

Z darem miłości małżeńskiej łączy się duchowość chrześcijańska, która ma charakter sakramentalny, a pogłębiana jest przez osobisty rozwój wewnętrzny każdej z osób w rodzinie na drodze cnót ${ }^{81}$. Należy budzić u małżonków radość poprzez zachęcanie ich do przystępowania do sakramentów świętych oraz korzystanie przez nich z sakramentaliów przeznaczonych do umocnienia życia całej ich rodziny ${ }^{82}$. Duchowość chrześcijańska, która tak szczególnie jest widoczna w życiu małżeńskim, jest odpowiedzią człowieka na powołanie Boże do obowiązków rodzicielskich. Małżonkowie są odpowiedzialni za siebie

\footnotetext{
${ }^{79}$ Por. E. Sakowicz, Duchowość małżeństwa, Homo Dei 71 (2001), nr 3, s. 58; H. KASPRZYK, Posłannictwo franciszkanów świeckich we współczesnym świecie, w: Duchowość franciszkanów świeckich, red. A. Baran, Lublin 2002, s. 119-120.

${ }^{80} \mathrm{Rdz} 1,27-28 \mathrm{a}$.

${ }^{81}$ Por. M. TAtar, Małżeństwo - w Kościele katolickim. Aspekt duchowy, w: Encyklopedia Katolicka, red. E. Ziemann, T. XI, Lublin 2006, k. 1080-1081.

${ }^{82}$ Por. IEP1, cz. III, nr 3.
} 
i za całą rodzinę, ale i za doprowadzenie do uświęcenia wszystkich osób. Kościół katolicki dostrzega w małżeństwie nie tylko formę wspólnego życia mężczyzny i kobiety, lecz także sakramentalne źródło uświęcenia i doskonalenia małżonków oraz zrodzonego przez nich potomstwa, w którym miłość jest integralnym czynnikiem ich szczęścia i wszechstronnego rozwoju.

W życiu wspólnoty rodzinnej nie można pominąć faktu, że centralnym wydarzeniem dnia świątecznego jest Msza Święta, która stanowi źródło życia duchowego całej rodziny ${ }^{83}$. Dzień świąteczny powinien być przeznaczony na pogłębienie życia duchowego w rodzinie, na podtrzymywanie oraz pielęgnowanie więzów rodzinnych ${ }^{84}$. Nieświętowanie powoduje osłabienie życia rodzinnego, a to prowadzi do zaniku życia religijnego u katolika, co również ma wpływ na całą rodzinę ${ }^{85}$. Eucharystia należy do najistotniejszych wydarzeń katolickiego świętowania każdej niedzieli i święta nakazanego. Udział w Eucharystii należy do nieodzownych elementów samego kultu Bożego, ponieważ Msza Święta ma zawsze charakter czynności społecznej Kościoła katolickiego. Ponadto przypomina o obowiązku udziału w dzień świąteczny w Eucharystii, nie tylko jako powinności wynikającej z prawa kanonicznego, ale także jako niezbędnym elemencie świadomego i pełnego życia chrześcijańskiego ${ }^{86}$. Uczestniczenie to polega na aktywnym zaangażowaniu się katolików, na obecności fizycznej, świadomej i czynnej ${ }^{87}$. Uczestnictwo we Mszy

${ }^{83}$ Por. KKK, nr 1343; E. BiAnchi, Vivere il giorno della chiesa, Liturgia 31(1997), s. 293-302.

${ }^{84}$ Por. GS, nr 67; DD, nr 52; J. Sкотnicki, Niedziela, w: Katolicyzm A-Z, red. Z. Pawlak, Łódź 1989, s. 296; H.J. Soвесzко, Elementy kultury świętowania niedzieli w Polsce, Roczniki Liturgiczne 56 (2009), nr 1, s. 427.

${ }^{85}$ Por. J. Sкотпіскі, Niedziela, art. cyt., s. 295; S. Сісну, Niedziela $w$ rodzinie, Ruch Biblijny i Liturgiczny 34 (1981), s. 46.

${ }^{86}$ Por. H.J. Sobeczko, Elementy kultury..., art. cyt., s. 424; A.M. CzajA, Czasy święte w prawodawstwie Kościoła katolickiego, Brodnica - Toruń 2013, s. 26.

${ }^{87} \mathrm{CIC}$, can. 835, $\$ 4$; por. can. 837, $\$ 2$; can. 898; W. PADACz, Czynny udział wiernych we Mszy św., Homo Dei XIX (1950), nr 6 (70), s. 840-852; J. KRukowski, Część III. Miejsca i czasy święte, w: Komentarz do Kodeksu Prawa Kanonicznego, T. III/2. Księga IV. Uświęcające zadanie Kościoła. Część I. Sakramenty. Część II. Pozostałe 
Świętej jest przede wszystkim odpowiedzią na miłość Boga, która najpełniej objawia się w Eucharystii. Dla chrześcijańskiej rodziny uroczysta Eucharystia jest głównym powodem radości i wspólnego przeżywania dnia świątecznego ${ }^{88}$. Katolicy, ubogaceni radością ze spotkania z Chrystusem w Ofierze Eucharystycznej, są zobowiązani tę radość zanieść do swoich rodzin.

Istotnym elementem dnia uroczystego jest także świętowanie go razem $z$ rodzinąa ${ }^{89}$, przez poświęcenie większej ilości czasu i uwagi najbliższym jej członkom ${ }^{90}$. Obowiązkiem jest jak najwięcej czasu spędzać z rodziną, gdyż temu celowi służy katolickie świętowanie, a zarazem jest to wyraz wzajemnej miłości ${ }^{91}$. Niepodważalny jest pogląd, że dzień świąteczny ma duży wpływ na rozwój życia rodzinnego, ponieważ daje okazję do budowania wspólnoty. Jako dzień modlitwy i wolny od pracy umożliwia poświęcenie więcej czasu najbliższym i nawiązanie relacji także $\mathrm{z}$ dalszą rodziną ${ }^{92}$. Często jest to jedyny dzień, w którym rodzice i dzieci mogą się razem spotkać, co ma znaczenie integrujące. Dzień świąteczny nie tylko ma umocnić ich wiarę, a także pogłębić wzajemną miłość małżonków i wszystkich członków rodziny, umożliwiając dawanie dobrego przykładu miłości w życiu małżeńskim i rodzinnym ${ }^{93}$. Na straży relacji rodzinnych stoi prawo kanoniczne, które zobowiązuje do przestrzegania wszelkich

akty kultu Bożego. Część III. Miejsca i czasy święte, red. tenże, Pallottinum 2011, s. 468 .

${ }^{88}$ Por. A. Durak, Niedziela $w$ rodzinie, w: Słownik małżeństwa rodziny, red. E. Ozorowski, Warszawa - Łomianki 1999, s. 299.

${ }^{89}$ Por. S. Cichy, Niedziela w rodzinie, art. cyt., s. 45.

${ }^{90}$ Por. H.J. Soвесzко, Elementy kultury, art. cyt., s. 427; S. Cichy, Niedziela w rodzinie, art. cyt., s. 45; A.M. CzAJA, Miejsca i czasy święte w aktualnym prawodawstwie kodeksowym i partykularnym, Toruń 2016, s. 196.

${ }^{91}$ Por. J. StaneK, Niedziela jest nam potrzebna, w: W komunii z Bogiem. Kościół domem i szkołą komunii. Program duszpasterski Kościoła w Polsce na lata 2010-2013. Rok 2010/2011, red. Sz. Sułkowski, Święty Wojciech-Poznań 2010, s. 304.

${ }^{92}$ Por. J. Sкот nicki, Niedziela, art. cyt., s. 297; H.J. Soвесzко, Elementy kultury..., art. cyt., s. 426; E. MARCZEwska, Eucharystia w życiu małżeństwa i rodziny, Novum 9 (1980), s. 126-138.

${ }^{93}$ Por. S. Cichy, Niedziela w rodzinie, art. cyt., s. 46-48. 
elementów dnia świątecznego, w tym także obowiązków związanych z małżeństwem i rodziną ${ }^{94}$.

W czasie dnia świątecznego rodzina powinna gromadzić się na wspólnych posiłkach przy jednym stole, a także na wartościowej rozrywce i przekazywaniu rodzinnych tradycji, ponieważ wszystko to umacnia wzajemne więzy, miłość i szacunek ${ }^{95}$. Ważnymi elementami tego dnia są także wspólne rozmowy, które mają zbliżyć do siebie. Należy to do zwyczajów godnych szczególnego praktykowania w życiu wspólnoty rodzinnej ${ }^{96}$. Powinno się także pamiętać o wspólnym zagłębieniu się w lekturze Pisma Świętego i literaturze czasopism religijnych, które powinny być dostępne w każdej katolickiej rodzinie ${ }^{97}$. Małżonkowie wraz z dziećmi nie powinni zamykać się tylko w kręgu najbliższej rodziny, ale wykorzystać czas wolny na odwiedzanie krewnych, przyjaciół i sąsiadów ${ }^{98}$, a szczególnie chorych, starszych i samotnych ${ }^{99}$. Ważne jest także odwiedzanie z rodziną cmentarza, na którym znajdują się groby zmarłych krewnych, żeby wspólnie pomodlić się za nich ${ }^{100}$.

\footnotetext{
${ }^{94}$ Por. A.M. Czaja, Miejsca i czasy..., dz. cyt., s. 184-200.

${ }^{95}$ Por. A. Durak, Niedziela $w$ rodzinie, art. cyt., s. 299; H.J. Sobeczкo, Elementy kultury..., art. cyt., s. 426.

${ }^{96}$ Ddr, nr 55; por. H.J. Soвесzко, Elementy kultury..., art. cyt., s. 426; J. SкотNicki, Niedziela, art. cyt., s. 297.

${ }^{97}$ Por. S. Cichy, Niedziela $w$ rodzinie, art. cyt., s. 46; J. Stanek, Niedziela jest..., art. cyt., s. 304.

${ }^{98}$ Por. J. Stanek, Niedziela jest..., art. cyt., s. 304; H.J. Sobeczko, Elementy kultury..., art. cyt., s. 428; M. Braun - GAŁKowska, Psychologia świętowania, w: Komisja Episkopatu Polski Duszpasterstwa Ogólnego. Program duszpasterski na rok 1992/93. Ewangelizacja i Eucharystia, Katowice 1992, s. 400-407.

${ }^{99} \mathrm{KKK}, \mathrm{nr} 2186$; por. H.J. Soвесzко, Elementy kultury..., art. cyt., s. 427; S. СicHY, Niedziela $w$ rodzinie, art. cyt., s. 49.

${ }^{100}$ Por. B. Wolański, Społeczny Ruch Świętowania Niedzieli, w: Być solą ziemi. Kościół domem i szkołą komunii. Program duszpasterski Kościoła w Polsce na lata 2010-2013. Rok 2012/2013, red. Sz. Stułkowski, Święty Wojciech - Poznań 2012, s. 408-409; A.M. CzaJA, Czasy święte..., dz. cyt., s. 34; S. Сісну, Niedziela w rodzinie, art. cyt., s. 48.
} 
Obowiązkiem rodziców względem swoich dzieci jest uczenie ich modlitw i pieśni chrześcijańskich oraz wierszy i pieśni patriotycznych, mówiących o miłości do Boga i ojczyzny. Powinni także opowiadać o historii ojczyzny, by rozbudzić w nich miłość do niej oraz szacunek do wszystkich ludzi. Gdy przyjdą zagrożenia, młodzi powinni umieć walczyć o wiarę chrześcijańską i wolną ojczyznę. Nie można zapominać o dziejach własnego rodu, o swoich przodkach. Należy również przekazać dzieje własnej rodziny przez pryzmat historii. Zadania, przed którymi stoją rodzice, winny być realizowane przez nich samych, głównie poprzez własny przykład ${ }^{101}$, ponieważ wszystko to służy rozwojowi życia rodzinnego i trwałości więzów międzypokoleniowych. Jednakże bez wzajemnej miłości wszystkich osób w rodzinie trudno budować wspólnotę małżeńsko-rodzinną. Na wszystkich płaszczyznach miłość występuje jako istotny czynnik scalający życie każdej wspólnoty. Choć nie jest ona ściśle instytucją prawną, to jednak należałoby ją uwzględnić zarówno przy stanowieniu prawa, jak i budowaniu wszelkich wspólnot, w tym także małżeńsko-rodzinnej.

\section{Miłość małżeńska strażnikiem życia ludzkiego}

Sprawdzianem posiadania miłości jest postawa troski o każde ludzkie życie od momentu poczęcia aż do śmierci naturalnej. Z małżeństwem i rodzicielstwem związana jest troska o życie ludzkie. Jest to objaw dojrzałości i miłości chrześcijańskiej. Obowiązek ten wynika z miłości, jaką obdarzył Bóg człowieka, dlatego osoby wierzące powinny popierać wszelkie inicjatywy promujące obronę życia na każdym jego etapie ${ }^{102}$. Wyrazem miłości są inicjatywy służące przeciwstawieniu się wszystkiemu, co jest szkodliwe w sprawach życia oraz wychowaniu dzieci i młodzieży.

Niedopuszczalne jest naruszenie daru życia przez aborcję, która jest zabójstwem dziecka. Człowiek od momentu poczęcia posiada

\footnotetext{
${ }^{101}$ Por. J. NagóRny, Odpowiedzialność za przyszłość, Lublin 2007, s. 191-197.

${ }^{102}$ Por. A. DzIĘGA, Pytania o rodzinę - niektóre kwestie dyskusyjne, w: Rodzina $\mathrm{w}$ prawie. Materiały z konferencji zorganizowanej w Stalowej Woli dnia 7 grudnia 2006 r., red. P. Telusiewicz, Stalowa Wola 2007, s. 51-54.
} 
wszystkie prawa osoby, a wśród nich: nienaruszalne prawo do życia, do rozwoju oraz do ochrony życia. Moralnie naganne jest również stosowanie środków antykoncepcyjnych, które wywołują skutki poronne, bądź nie dopuszczają do poczęcia dziecka. Antykoncepcja nie jest zgodna z zasadami etyki chrześcijańskiej, a wykroczenia w tym zakresie są grzechem ciężkim. Niedopuszczalne jest także obezpłodnienie, zarówno stałe, jak i czasowe, tak kobiety, jak i mężczyzny ${ }^{103}$. Nauczanie Kościoła katolickiego na ten temat jest niezmienne.

Życie ludzkie jest wielkim darem miłości Boga wobec człowieka. Wszyscy mają obowiązek i prawo bronić oraz szanować istnienie osoby ludzkiej od momentu jej poczęcia aż do naturalnej śmierci ${ }^{104}$. Kościół katolicki od początku naucza, że złem jest zabicie człowieka. Obok Pisma Świętego należy wskazać na jedno z najstarszych dzieł chrześcijańskich Didache, gdzie czytamy: „Nie zabijaj dzieci przez przerwanie, ani nie przyprawiaj ich o śmierć już po urodzeniu”105. Natomiast Konstytucja soborowa Gaudium et spes stwierdza: „Bóg bowiem, Pan życia, powierzył ludziom wzniosłą posługę strzeżenia życia, którą człowiek powinien wypełniać w sposób godny siebie. Należy więc z największą troską ochraniać życie od samego jego poczęcia; przerwanie ciąży, jak i dzieciobójstwo są okropnymi przestępstwami”"106. Z kolei w Katechizmie Kościoła Katolickiego czytamy: „Życie ludzkie od chwili poczęcia powinno być szanowane i chronione w sposób absolutny. Już od pierwszej chwili swego istnienia istota ludzka powinna mieć przyznane prawa osoby, wśród nich

${ }^{103}$ WSZSM, cz. 2; por. JAN PAWeŁ II, Mężczyzna i niewiasta stworzył ich. Odkupienie ciała a sakramentalność małżeństwa, Watykan 1986, s. 401; I. WERBIŃsKi, Antykoncepcja, w: Słownik małżeństwa i rodziny, red. E. Ozorowski, Warszawa - Łomianki 1999, s. 18-19

${ }^{104}$ Por. W. Tabaczyński, Prawo do życia, w: Słownik małżeństwa i rodziny, red. E. Ozorowski, Warszawa - Łomianki 1999, s. 367.

${ }^{105}$ Nauka dwunastu Apostołów (Didache). Nauka Pana, która dwunastu Apostołów przekazało narodom, w: Pierwsi świadkowie. Pisma Ojców Kościoła, red. M. Starowiejski, Kraków 1998, s. 33-34.

${ }^{106}$ GS, nr 51; por. KKK, nr 2271. 
nienaruszalne prawo każdej niewinnej istoty do życia”"107. Inny dokument Stolicy Apostolskiej „Karta Praw Rodziny”, wyraźnie wskazuje na absolutny obowiązek ochrony i szacunku dla życia ludzkiego na każdym etapie jego istnienia ${ }^{108}$.

Zamierzone zabicie dziecka jest głęboko sprzeczne z Bożym prawem. Każdy, kto świadomie i dobrowolnie współdziała w aborcji, przez wykonanie tego czynu lub pomagając, bądź do niego nakłaniając, nawet $\mathrm{w}$ formie rady, oprócz grzechu ciężkiego zaciąga mocą samego prawa kanonicznego po dokonaniu zabicia dziecka karę ekskomuniki, najcięższej sankcji w Kościele katolickim ${ }^{109}$. Ekskomunika należy do kar poprawczych i ma na celu doprowadzenie katolika do poprawy oraz naprawienia wywołanego zgorszenia, a także wyrównanie naruszonej sprawiedliwości ${ }^{110}$. Kościół w ten sposób ukazuje ciężar popełnionej zbrodni, krzywdę wyrządzoną zamordowanemu dziecku, jego rodzicom, rodzinie oraz całemu społeczeństwu ${ }^{111}$. Kara może zostać cofnięta, gdy winowajca uzna swój grzech, wykaże żal za popełnione zło, postanowi poprawę i prosić będzie o pojednanie z Bogiem i Kościołem.

Wśród podstawowych norm, wynikających z prawa Bożego, należy wymienić także prawo do naturalnej śmierci. Niedopuszczalna jest eutanazja, która polega na uśmierceniu osób chorych, starszych bądź upośledzonych. Osoby o ograniczonej sprawności mają niezbywalne prawo do życia, szacunku i opieki. Powinny być również tak wspierane, by mogły prowadzić normalne życie ${ }^{112}$. Eutanazja nie

\footnotetext{
${ }^{107}$ KKK, nr 2270; por. W. TABACZyński, Prawo do życia, art. cyt., s. 367.

${ }^{108} \mathrm{KPR}$, art. 4; por. G. PyźLAK, Recepcja przygotowania do matżeństwa w świetle badań narzeczonych, Lublin 2007, s. 88.

${ }^{109}$ CIC, can. 1398; por. F. Lempa, Część szczegółowa, w: Komentarz do Kodeksu Prawa Kanonicznego z 1983 r. Księga V. Dobra doczesne Kościoła. Księga VI. Sankcje w Kościele, red. W. Wójcik [i in.], T. 4, Lublin 1987, s. 278.

${ }^{110}$ Por. CIC, can. 1341; J. Krukowski, Część ogólna, w: Komentarz do Kodeksu Prawa Kanonicznego z 1983 r. Księga V. Dobra doczesne Kościoła. Księga VI. SAnkcje w Kościele, red. W. Wójcik [i in.], T. 4. Lublin 1987, s. 164-168.

${ }^{111}$ Por. KKK, nr 2272; G. PyźLAK, Recepcja przygotowania..., dz. cyt., s. 89.

${ }^{112}$ KKK, nr 2276-2277.
} 
powinna być wykonywana, nawet jeżeli chce jej chory, jego rodzina lub sugeruje ją służba medyczna. Gdy ustawodawstwo państwowe pozbawia obrony istotę ludzką, którą ze swej natury powinno bronić, neguje równość wszystkich wobec prawa. Zapewnienie ochrony życia ludzkiego od zawsze należy do podstawowych zadań władzy państwowej ${ }^{113}$.

$\mathrm{Z}$ faktu niezbywalnej godności człowieka wynika bezwzględna ochrona każdego życia ludzkiego. Dlatego potrzebny jest sprzeciw, nie tylko wobec aborcji i eutanazji, ale również wobec zapłodnienia pozaustrojowego in vitro. Instrukcja Kongregacji Nauki Wiary Dignitas personae apeluje szczególnie do sumień rodziców, lekarzy, naukowców oraz polityków o odwagę i skuteczność w obronie życia i godności człowieka ${ }^{114}$. Nie jest dopuszczalne niszczenie istnienia ludzkiego na jakimkolwiek etapie jego życia. Zło związane z metodą in vitro nie wynika tylko $\mathrm{z}$ faktu, że w trakcie tej procedury zabija się dzieci, które istnieją na swym naturalnym bardzo wczesnym etapie, ale także z tego, że metoda ta czyni człowieka przedmiotem manipulacji, gdyż traktuje go jako przedmiot w procesach określonej biotechnologii, a tęsknota małżonków za posiadaniem dziecka jest stawiana ponad jego niezbywalną godność. Pomocą dla małżonków borykających się z problemem niepłodności jest naprotechnologia, która polega na leczeniu niepłodności. Z uwagi na ochronę godności i życia każdego człowieka, metoda zapłodnienia in vitro powinna być prawnie zakazana. Dlatego obowiązkiem jest sprzeciw, także wobec zapłodnienia pozaustrojowego in vitro ${ }^{115}$.

Święty Jan Paweł II nauczał, że osoby pozbawiające życia przez aborcję lub eutanazję, których żadna ludzka ustawa nie może uznać za dopuszczalne, są zbrodniami. Natomiast ustawy prawodawstwa państwowego, które to czynią, nie są w żaden sposób wiążące dla sumienia, jednocześnie stawiają człowieka wobec powinności

\footnotetext{
${ }^{113}$ Por. K. Wiak, Prawna ochrona..., art. cyt., s. 275.

${ }^{114}$ Kongregacja Nauki Wiary, Instrukcja Dignitas personae, dotyczaca niektórych problemów bioetycznych, Pallottinum 2008 (dalej: DP), nr 1-37.

${ }^{115}$ DP, nr 1-37; por. Jan PaweŁ II, Mężczyzna i niewiasta..., dz. cyt. , s. 473.
} 
przeciwstawienia się im. W przypadku prawa wewnętrznie niesprawiedliwego, jakim jest prawo dopuszczające zabijanie dzieci, eutanazję i in vitro, nie wolno się nigdy do niego stosować ani uczestniczyć w popieraniu takiego przepisu. Papież przypomniał, że nie można stawiać prawa państwowego ponad prawem moralnym, ponieważ prawo niesprawiedliwe nie przestaje nim być nawet wtedy, gdy jest zalegalizowane przez ustawodawstwo danego kraju ${ }^{116}$. Normy etyczne są jednoznaczne i niezmienne. Każdy człowiek, a szczególnie katolik, nie jest zobowiązany do respektowania niesprawiedliwej normy prawa państwowego, dopuszczającej zabicie człowieka. Obowiązkiem każdej osoby jest stać na straży życia - od poczęcia aż do naturalnej śmierci. Zgoda matki i ojca, czy też prawodawstwa państwowego na zabicie nienarodzonego człowieka, nie może usprawiedliwiać czynu przestępczego.

Niezbywalne prawa osoby ludzkiej powinny być uznawane i szanowane przez społeczeństwo i władzę państwową. Prawa człowieka nie zależą od rodziców, ani nie pochodzą od społeczeństwa lub państwa, lecz tkwią w naturze ludzkiej i są ściśle związane z osobą na mocy aktu stwórczego Boga, od którego każdy człowiek bierze swój początek jako dar miłości. Wyrazem szacunku, opieki należnej osobie, począwszy od momentu jej poczęcia aż do naturalnej śmierci, powinny być przewidziane przez prawodawstwo państwowe odpowiednie kary za każde dobrowolne i świadome pogwałcenie jej praw $^{117}$. Troska o ludzkie życie na każdym jego etapie istnienia jest wyrazem miłości. Natomiast eutanazja, aborcja i in vitro są czynami, które należy potępić i nigdy do nich nie dopuścić. Są także przejawem braku miłości w osobie, która je czyni. Małżeństwo, jako instytucja, jest powołane także do troski o każde życie, bo w swej istocie zawiera dar nowego życia.

\footnotetext{
${ }^{116} \mathrm{EV}, \mathrm{nr} 73$.

${ }^{117}$ DVi, cz. III; por. EV, nr 11.
} 


\section{Wnioski}

Miłość małżeńska jest ważnym czynnikiem, który wchodząc w zakres życia małżeńsko-rodzinnego stanowi jego element integrujący. Nie ma ona wprost waloru prawnego, jednak spełnia bardzo ważną rolę w życiu człowieka. Bez niej małżonkowie są pozbawieni bodźców, które wpływają pozytywnie na wypełnianie celów i przymiotów małżeńskich. Gdy nie ma miłości między narzeczonymi, może pojawić się wykluczenie któregoś z nich, a także wystąpić brak woli zawarcia ślubu, co powoduje w każdym przypadku nieważność małżeństwa. Miłość małżeńska jest ważna dla pewności wyrażenia prawidłowo zgody małżeńskiej oraz odpowiedzialnego, dobrego wypełniania obowiązków małżeńskich i rodzicielskich.

Miłość małżeńska ułatwia realizację zadań, stojących przed małżonkami w kwestii rodzicielskiej. Brak miłości przeważnie jest powodem awersji pomiędzy nimi, dlatego odpowiedzialne zawieranie małżeństwa uwzględnia posiadanie miłości, która powinna znajdować się u podłoża wspólnego życia. Chociaż miłość nie jest konieczna do ważności, z punktu widzenia prawa kanonicznego, ma natomiast istotne znaczenie w życiu małżeńskim. Nie ma wątpliwości, że miłość kobiety i mężczyzny, których pragnieniem jest żyć razem, wpływa pozytywnie na wyrażenie zgody małżeńskiej oraz wzajemne oddanie się i przyjęcie.

Miłość, która jest elementem duchowości małżeńskiej, jest też odpowiedzią człowieka na powołanie Boże do obowiązków rodzicielskich. Małżonkowie są odpowiedzialni za siebie i za całą rodzinę, za rozwój wiary chrześcijańskiej, za uświęcenie i zbawienie wszystkich członków. Wielką rolę w umacnianiu miłości ma Sakrament Najświętszej Eucharystii, który jest źródłem życia i siłą dla całej rodziny. Małżeństwo i rodzina przynależą do porządku naturalnego i nadprzyrodzonego, które prowadzą chrześcijan do świętości.

Nie można rozdzielać instytucji małżeństwa od wspólnoty rodzinnej, która dopełnia i wewnętrznie ubogaca małżeństwo poprzez przyjęcie daru nowego życia, jakim są dzieci. Rodzina stanowi podstawową komórkę życia społecznego. Jednakże jest ona narażona na niebezpieczeństwa, ze względu na tendencje osłabiania trwałości 
małżeństwa i zastępowania go związkami nieformalnymi. Zagrożenie dla każdego społeczeństwa stanowi przyznawanie przez niektóre prawodawstwa państwowe statusu małżeństwa związkom między osobami tej samej płci oraz brak poszanowania prawa do życia dzieci poczętych, jak i propagowanie w wychowaniu dzieci i młodzieży jeszcze innych postaw sprzecznych z chrześcijańskimi zasadami.

\section{Significance of marital love in the canonical and pastoral aspect}

Love is an important integrating factor of the marital-family life. It is not a legal entity; however, it plays a very important role in the life of man. Without love spouses are deprived of stimuli which contribute greatly and enable to achieve goals set for the marriage. When there is no love between fiancées, one of them might become alienated, they may also be unwilling to get married as result, which in turn would lead to declaring their marriage invalid in both cases. Marital love is crucial to ensure the expression of marital harmony between husband and wife properly and to perform conjugal and parental duties in a responsible way. The Roman Catholic Church, from the beginning of its apostolic activity, has protected the value of marriage and family with constant prayer, special concern and the blessing. Marital love has a primary importance in the entire community of life of a married couple. It is essential for their mutual and full development. Love is an important integrating factor of the marital life. Marital love facilitates the execution of tasks that spouses and then parents have to do. Excluding the above-mentioned goals set for the marriage as well as defects in the agreement between the spouses result in the fact the marriage is invalid. Responsible marriage is inseparable of love, which should be the basis for the conjugal life of the couple. There is no denying that love of the spouses, whose desire is to live together, contributes greatly to the marital harmony between husband and wife and stimulates mutual devotion and acceptance of the couple.

SŁowA KLUCzowE: miłość; małżeństwo; rodzina; sakrament

KEY WORDS: love; marriage; family; sacrament 
Nota o Autorze:

O. Arkadiusz MirosŁaw Czaja OFM - doktor nauk prawnych; kapłan Zakonu Braci Mniejszych Prowincji Świętego Franciszka z Asyżu; wykładowca prawa kanonicznego na Wydziale Teologicznym Uniwersytetu Adama Mickiewicza w Poznaniu; przewodniczący Komisji Prawnej w Prowincji św. Franciszka z Asyżu i Komisji Statutowej Rady Narodowej Franciszkańskiego Zakonu Świeckich w Polsce; sędzia Sądu Biskupiego Diecezji Toruńskiej. 